\title{
The antecedence of lecturer's OCB: Evidence from Indonesia
}

\author{
Widodo Widodo ${ }^{a^{*}}$ and Robertus M. B. Gunawan ${ }^{\mathrm{b}}$
}

${ }^{a}$ Faculty of Education and Social Sciences of Indraprasta University, Jakarta, Indonesia ${ }^{b}$ Pelita Harapan University, Jakarta, Indonesia

\section{CH R O I C L E A B S T RACT}

\begin{tabular}{l} 
Article history: \\
Received: February 2, 2020 \\
Received in revised format: \\
March 72020 \\
Accepted: March 7, 2020 \\
Available online: \\
March 9, 2020 \\
\hline Keywords: \\
Organizational citizenship behav- \\
ior (OCB) \\
Learning organization \\
Reward system \\
Organizational commitment
\end{tabular}

\begin{abstract}
This research explores the antecedence of the lecturer's organizational citizenship behavior (OCB) of the private higher education in Indonesia. This research used a quantitative approach with a survey method. The sample of this research is 190 lecturers selected by purposive sampling. The data were obtained by spreading questionnaires and analyzing with path analysis based on supporting descriptive statistics and correlation. The results of research confirm that learning organization, reward system, and organizational commitment had a significant direct effect on OCB, learning organization and reward system had a significant direct effect on organizational commitment, and learning organization and reward system had a significant indirect effect on OCB by mediating organizational commitment. A fit research model was found about the effect of learning organization and reward system on OCB by mediating organizational commitment. This model can be discussed as a reference by researchers and practitioners in developing models of OCB in the future.
\end{abstract}

\section{Introduction}

Private higher education in Indonesia has not shown their existence as an educational institution whose responsibilities of human resources development. Based on the ranking of the Ministry of Research, Technology and Higher Education of The Republic of Indonesia in 2019, none of the 3940 private higher education in Indonesia was ranked in the top 10 . Telkom University as a private university which is ranked the best (14). At the international level, Telkom University only ranks 533 in Asia and 1906 in the world version of Webometrics, which means the private higher education in Indonesia is embracing a high organizational citizenship behavior (OCB) from lecturers as the main actors in the teaching, research, and community service process. OCB is employee actions carried out based on volunteerism and outside of their role that can make a positive contribution to effective and efficient on the organization (Tschannen-Moran, 2004; Organs in Günay, 2018). In another word, OCB is individual behavior that is not regulated by the organization, and that reward systems are not formally calculated, for example, to help a colleague work overtime if needed, but this behavior will drive the effectiveness of the overall functioning of the organization (Peleaşă, 2018; Spitzmuller et al., in Hanafi et al. 2018). Organs as quoted by Tschannen-Moran (2004) identifies five indicators that can be used as parameters to measure OCB, namely: altruism, conscientiousness, courtesy, sportsmanship, and civic virtue. Based on several research and studies in various countries, industrial, and occupational sectors, OCB among others influenced learning organization, reward system, and organizational commitment.

\section{Theoretical Framework and Hypothesis Development}

\subsection{Learning Organization and $O C B$}

Learning organizations reflects the acquisition of knowledge through the application and mastery of new information, tools, and methods to transform themselves (Pedler et al., 1997; White \& Burton, 2007). Senge (1990:3) argues that "learning 
organizations are organizations where members continually expand their capacity to create the results they really want, where new expansive patterns of thought are fostered, collective aspirations are freed, and people continually learn to see the whole organization together." The learning organization can be measured by four indicators, namely managerial commitment, system perspective, openness and experimentation, knowledge transfer and integration (Jerez-Gomez et al., 2005). These indicators, in practice, can be realized for developing OCB. As shown in some studies that learning organizations influence OCB, for example, Dirani (2009), Basim et al. (2009), Jo and Joo (2011), and Arma et al. (2016). Based on the studies and statements, the first hypothesis in this study is:

\section{$\mathrm{H}_{1}$ : Learning organization has a direct effect on OCB.}

\subsection{Reward System and $O C B$}

Rewards referring to various organizational activities aimed at allocating compensation financial and benefits to employees in return for efforts and contributions made to achieve organizational goals (McKenna, 2006; Bernardin, 2007). According to Greenberg (2010:362), "reward system should generously and fairly recognize individual' contributions, but they should not be so specific as to connect every move to a bonus or some type of monetary reward." Rewards are all extrinsic rewards received by employees in exchange of work consisting of basic salary, incentives or bonuses, and benefits (Byars \& Rue, 2008), which consist of seven indicators, namely: wages/salaries, benefits, additional income, feelings of ability, skills, personal growth, and responsibilities (Vecchio, 2008). The results of research by Suresh and Venkatammal (2010), Sinnappan and Amulraj (2014), Choi et al. (2015), Rahman and Chowdhuri (2018), and Suryani et al. (2019) shows that reward system influences OCB. Based on the studies and statements, the second hypothesis in this study is:

\section{$\mathrm{H}_{2}$ : Reward system has a direct effect on OCB.}

\subsection{Organizational Commitment and $O C B$}

Organizational commitment is "an emotional bond, partisanship, and involvement in a particular organization" (McShane \& Von Glinow, 2015:119), and "a state in which an employee identifies with a particular organization and its goals and wishes to maintain membership in the organization" (Robbins \& Judge, 2017:74). According to Mowday, Porter, and Steers as quoted by Slocum and Hellriegel (2007:328), “organizational commitment refers to the strength of an employee's involvement in the organizational and identification with it, a support of and acceptance of the organization's goals and values, a willingness to exert considerable effort on behalf of the organization, and a desire to remain with the organization." Thus, when the organizational commitment of employees is high, it means that the alignments with the organization are also high. In organizational commitment, there are several components can be used as indicators in a study, namely affective, normative, and continuance (Meyer \& Allen, 1997). These indicators if developing in a good condition can be influences OCB. The results of the study which concluded that organizational commitment affects OCB, including among others conducted by Saxena dan Saxena (2015), Suwibawa et al. (2018), Kusumaninggati et al. (2018), and Shahjehan et al. (2019). Based on the studies and statements, the third hypothesis in this study is:

$\mathrm{H}_{3}$ : Organizational commitment has a direct effect on OCB.

\subsection{Learning Organization and Organizational Commitment}

Organizational commitment in addition to influencing OCB but in other conditions also influenced by the learning organization. The indicators of learning organization which is reflected in managerial commitment, system perspective, openness and experimentation, knowledge transfer and integration (Jerez-Gomez et al., 2005) if in good conditions can be realized for stimulating affective, normative, and continuance commitment (Meyer \& Allen, 1997). The results of research carried out by Balay (2012), Rahman and Awang (2013), Bikmaradi et al. (2018), Maulana et al. (2019), and Beauregard et al. (2019) show that learning organization affects organizational commitment. Based on the studies and statements, the fourth hypothesis in this study is:

$\mathrm{H}_{4}$ : Learning organization has a direct effect on organizational commitment.

\subsection{Reward System and Organizational Commitment}

The Reward system also influenced organizational commitment. While indicators of a reward system, as wages/salaries, benefits, additional income, feelings of ability, skills, personal growth, and responsibilities (Vecchio, 2008) in good condition, that is can encourage the onset of affective, normative, and continuance commitment (Meyer \& Allen, 1997). As shown in several studies conducted by Williamson et al. (2009), Saqib et al. (2015), Chelangat and Gachunga (2016), Nazir et al. (2016), and Widodo and Damayanti (2020) that reward system affects organizational commitment. Based on the studies and statements, the fifth hypothesis in this study is:

$\mathrm{H}_{5}$ : Reward system has a direct effect on organizational commitment. 


\section{Research Methods}

This research uses a quantitative approach to survey methods. The survey involved a research sample of 190 permanent lecturers of private higher education in Indonesia spread across 10 provinces determined by purposive sampling based on certain characteristics (Widodo, 2019). The number of samples is by following the criteria of Hair et al. (2010) that sample size is five to ten times the number of indicators (observations) of all research variables. The number of indicators (observations) of the four latent variables in this study is 19 , so if multiplied by ten $=190$. The details: four indicators of learning organization variables, namely: managerial commitment (MC); system perspective (SP); openness and experimentation (OE); knowledge transfer and integration (KTI) (Jerez-Gomez, Cespedes-Lorente, \& Valle-Cabrera, 2005), seven indicators of reward system variables, namely: wages/salaries (Wag), benefits (Ben), additional income (AI), feeling of being able (FBA), skills (Ski), personal growth (PG), and responsibility (Rsp) (Vecchio, 2008), three indicators of organizational commitment variables, namely: affective (Aff), normative (Nor), and continuance (Con) (Meyer \& Allen, 1997), and five OCB variable indicators, namely: altruism (Alt), conscientiousness (Cons), courtesy (Crt), sportsmanship (Spr), and civic virtue (CV) (Organs in Tschannen-Moran, 2004). The data was collected by a questionnaire in the form of a Likert scale model with five alternative answers: strongly disagree, disagree, neutral, agree, and strongly agree. The questionnaire was made by researchers themselves based on the theoretical indicators of the experts. The learning organization questionnaire consists of 12 items with an alpha coefficient $=.954$, the reward system consists of 10 items with an alpha coefficient $=.889$, organizational commitment consists of 10 items with an alpha coefficient $=.837$, and OCB consists of 10 items with alpha coefficients $=.877$. Data analysis using the path analysis and to test the significance of the path coefficient uses a t-test by Lisrel 8.80. The profile of respondents as research samples is described in Fig.1.

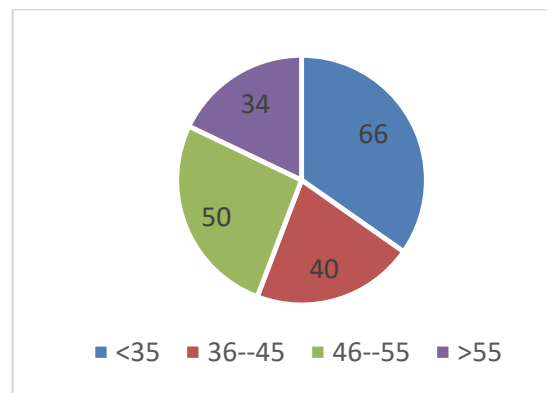

Age

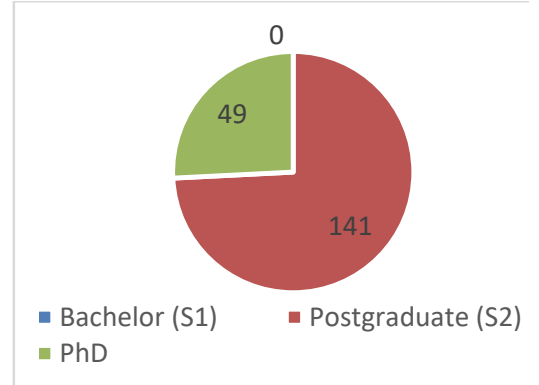

Fig. 1. Personal characteristics of the participants

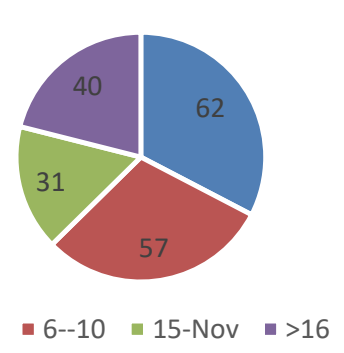

Years of experience

The majority of gender is male $(65.79 \%)$, ages 26 - 35 years $(34.74 \%)$, postgraduate education $(74.21 \%)$, marital status $(87.89 \%)$, and length of work $<5$ years $(32,63 \%)$. Moreover, nearly $88 \%$ of the participants in this survey were married.

\section{Research Results}

The results of the descriptive statistical analysis for the four research variables are presented as followed in Table 1. As shown in Table 1, the mean values of the four variables from the lowest to the highest in succession are reward system (38.20), OCB (40.45), organizational commitment (41.52), and learning organization (48.11). Table 2 shows all indicators on each variable have significant relationships with the indicators of the other variables at level $p<.05$. This condition indicates that all the indicators of all variables had a mutual relationship with each other.

Table 1

Descriptive Statistics

\begin{tabular}{|c|c|c|c|c|c|}
\hline & & Learning & Reward System & Organizational Commitment & OCB \\
\hline \multirow[t]{2}{*}{$\mathrm{N}$} & Valid & 190 & 190 & 190 & 190 \\
\hline & Missing & 0 & 0 & 0 & 0 \\
\hline Mean & & 48.11 & 38.20 & 41.52 & 40.45 \\
\hline Median & & 51.00 & 39.00 & 41.00 & 40.00 \\
\hline Mode & & 60 & 40 & 40 & 40 \\
\hline Std. Deviation & & 10.444 & 6.461 & 4.584 & 6.435 \\
\hline Variance & & 109.079 & 41.748 & 21.013 & 41.413 \\
\hline Range & & 46 & 34 & 30 & 40 \\
\hline Minimum & & 14 & 16 & 20 & 10 \\
\hline Maximum & & 60 & 50 & 50 & 50 \\
\hline Sum & & 9140 & 7258 & 7889 & 7686 \\
\hline
\end{tabular}

The results of hypothesis testing with path analysis of the effects of learning organization and reward system on organizational commitment and OCB are summarized in Table 3 and visualized in Fig. 2 and Fig. 3. The test results in Table 3 show that all hypotheses were supported ( $\mathrm{t}$-value $>\mathrm{t}$-table at $\alpha=.01$ ). Therefore, the results of this study indicate that learning organization, reward system, and organizational commitment had a significant direct effect on OCB, then learning organization and reward systems had a significant direct effect on organizational commitment. 
Table 2

Correlation matrix of indicators

\begin{tabular}{|c|c|c|c|c|c|c|c|c|c|c|c|c|c|c|c|c|c|c|c|}
\hline & 1 & 2 & 3 & 4 & 5 & 6 & 7 & 8 & 9 & 10 & 11 & 12 & 13 & 14 & 15 & 16 & 17 & 18 & 19 \\
\hline \multicolumn{20}{|c|}{ Learning } \\
\hline 1. MC & 1.00 & & & & & & & & & & & & & & & & & & \\
\hline 2. SP & $.83^{*}$ & 1.00 & & & & & & & & & & & & & & & & & \\
\hline 3. $\mathrm{OE}$ & $.76 *$ & $.79^{*}$ & 1.00 & & & & & & & & & & & & & & & & \\
\hline \multirow{2}{*}{\multicolumn{20}{|c|}{ Reward System }} \\
\hline & & & & & & & & & & & & & & & & & & & \\
\hline 5. Wag & $.38^{*}$ & $.37^{*}$ & $.46^{*}$ & $.39 *$ & 1.00 & & & & & & & & & & & & & & \\
\hline 6. Ben & $.37 *$ & $.40^{*}$ & $.44 *$ & $.40^{*}$ & $.88^{*}$ & 1.00 & & & & & & & & & & & & & \\
\hline 7. $\mathrm{AI}$ & $.36^{*}$ & $.32 *$ & $.31 *$ & $.34 *$ & $.66^{*}$ & $.68^{*}$ & 1.00 & & & & & & & & & & & & \\
\hline 8. FBA & $.59 \%$ & $.59 *$ & $.57 *$ & $.60^{*}$ & $.54 *$ & $.55^{*}$ & $.55^{*}$ & 1.00 & & & & & & & & & & & \\
\hline 9. Ski & $.63 *$ & $.62 *$ & $.63 *$ & $.63^{*}$ & $.61^{*}$ & $.61 *$ & $.51 *$ & $.80^{*}$ & 1.00 & & & & & & & & & & \\
\hline 10. PG & $.62 *$ & $.59 *$ & $.58^{*}$ & $.59 *$ & $.51 *$ & $.53^{*}$ & $.49 *$ & $.76 \%$ & $.74^{*}$ & 1.00 & & & & & & & & & \\
\hline 11. Rsp & $.40^{*}$ & $.40^{*}$ & $.36^{*}$ & $.42 *$ & $.46^{*}$ & $.43^{*}$ & $.47^{*}$ & $.54^{*}$ & $.49 *$ & $.60^{*}$ & 1.00 & & & & & & & & \\
\hline \multicolumn{20}{|c|}{$\begin{array}{c}\text { Organizational } \\
\text { Commitment }\end{array}$} \\
\hline 12. Aff & $.31 *$ & $.31 *$ & $.35 *$ & $.32 *$ & $.25^{*}$ & $.24^{*}$ & $.23^{*}$ & $.26^{*}$ & $.37 *$ & $.31 *$ & $.30^{*}$ & 1.00 & & & & & & & \\
\hline 13. Nor & $.36 *$ & $.30^{*}$ & $.38^{*}$ & $.35^{*}$ & $.24 *$ & $.25^{*}$ & $.24 *$ & $.40^{*}$ & $.35 *$ & $.36^{*}$ & $.36 *$ & $.47^{*}$ & 1.00 & & & & & & \\
\hline 14. Con & $.54 *$ & $.56^{*}$ & $.54 *$ & $.57 *$ & $.47 *$ & $.47 *$ & $.50 *$ & $.55^{*}$ & $.58 *$ & $.50^{*}$ & $.52 *$ & $.66^{*}$ & $.55^{*}$ & 1.00 & & & & & \\
\hline \multicolumn{20}{|l|}{ OCB } \\
\hline 15. Alt & $.52 *$ & $.46^{*}$ & $.46^{*}$ & $.51^{*}$ & $.39 *$ & $.38^{*}$ & $.33^{*}$ & $.41^{*}$ & $.53 *$ & $.43 *$ & $.37 *$ & $.52 *$ & $.35^{*}$ & $.58^{*}$ & 1.00 & & & & \\
\hline 16. Cons & $.38^{*}$ & $.35^{*}$ & $.38^{*}$ & $.39 *$ & $.33^{*}$ & $.32 *$ & $.31 *$ & $.41^{*}$ & $.46 *$ & $.40^{*}$ & $.42 *$ & $.44 *$ & $.38^{*}$ & $.51 *$ & $.62^{*}$ & 1.00 & & & \\
\hline 17. Crt & $.42^{*}$ & $.41^{*}$ & $.44^{*}$ & $.38^{*}$ & $.33^{*}$ & $.36^{*}$ & $.32 *$ & $40^{*}$ & $.43 *$ & $.41^{*}$ & $.39 *$ & $.45^{*}$ & $.35^{*}$ & $.54 *$ & $.58^{*}$ & $.57^{*}$ & 1.00 & & \\
\hline 18. Spr & $.47 *$ & $.45^{*}$ & $.59 *$ & $.45^{*}$ & $.40^{*}$ & $.41^{*}$ & $.25^{*}$ & $.55^{*}$ & $.60^{*}$ & $.53 *$ & $.39 *$ & $.26^{*}$ & $.47 *$ & $.46^{*}$ & $.56^{*}$ & $.56 *$ & $.52 *$ & 1.00 & \\
\hline $\begin{array}{l}\text { 18. } \mathrm{spr} \\
19 . \mathrm{V}\end{array}$ & $.52 *$ & $.55 \%$ & $.51 *$ & $.49^{*}$ & $.49^{*}$ & $.38^{*}$ & $.27^{*}$ & $.42 *$ & $.05^{*}$ & $.42 *$ & $.36 *$ & $.54^{*}$ & $.38^{*}$ & $.61 \%$ & $.62 *$ & $.54 *$ & $.53^{*}$ & $.53^{*}$ & 1.00 \\
\hline
\end{tabular}

Table 3

Summary of path coefficients and $t$ values

\begin{tabular}{|c|c|c|c|}
\hline Hypothesis & Path Coefficients & T Value & Hypothesis Testing \\
\hline $\mathrm{H}_{1}$ : Learning organization $\left(\mathrm{X}_{1}\right)$ on $\mathrm{OCB}\left(\mathrm{Y}_{2}\right)$ & $.23^{* *}$ & 3.63 & Supported \\
\hline $\mathrm{H}_{2}:$ Reward system $\left(\mathrm{X}_{2}\right)$ on $\mathrm{OCB}\left(\mathrm{Y}_{2}\right)$ & $.22 * *$ & 3.39 & Supported \\
\hline $\mathrm{H}_{3}$ : Organizational commitment $\left(\mathrm{Y}_{1}\right)$ on $\mathrm{OCB}\left(\mathrm{Y}_{2}\right)$ & $.44 * *$ & 7.48 & Supported \\
\hline $\mathrm{H}_{4}$ : Learning organization $\left(\mathrm{X}_{1}\right)$ on Organizational commitment $\left(\mathrm{Y}_{1}\right)$ & $.32 * *$ & 4.14 & Supported \\
\hline $\mathrm{H}_{5}:$ Reward system $\left(\mathrm{X}_{2}\right)$ on Organizational commitment $\left(\mathrm{Y}_{1}\right)$ & $.34 * *$ & 4.40 & Supported \\
\hline
\end{tabular}

$* * \mathrm{p}<.01$

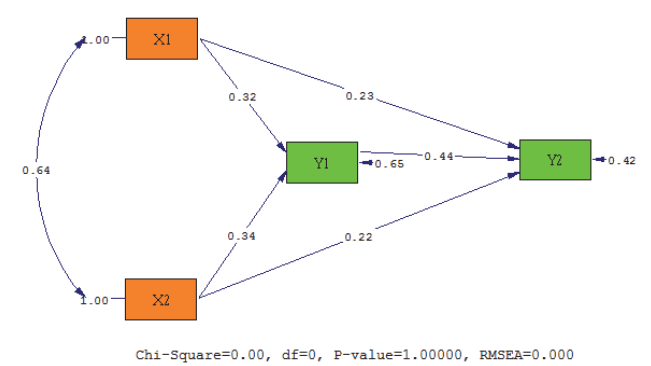

Fig. 2. Path Coefficients

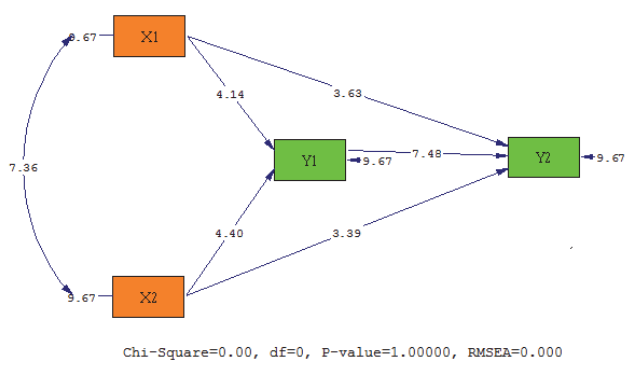

Fig.3. T Values

In addition, the results of this study also show learning organization and reward system had a significant indirect effect on OCB by mediating organizational commitment, each with path coefficient $=.014^{* *}$ and $.015^{* *}$ and $\mathrm{t}$-value $=3.62$ and 3.79 . In Fig. 2 and Fig. 3, the test results of the model with goodness of fit statistics show the significant with Chi-Square $=0.000$, $\mathrm{df}=0, \mathrm{p}$-value $=1.00000>.05$ and RMSEA $=.000<.08$, so that the model tested is fit. That means the theoretical model being tested is supported by empirical data.

\section{Discussion}

The results have indicated that the learning organization and reward system had a significant effect on OCB, either directly or indirectly by mediating organizational commitment. The results of the correlation test between indicators for all variables as a whole show a significant relationship. Finally, the result of a fit model test also shows that the theoretical model was in accordance (fit) with empirical data. This finding confirms that learning organization, reward system, and organizational commitment are strong antecedents for OCB. Moreover, organizational commitment plays a significant role as a mediator of the influence of learning organizations and reward systems on OCB. These findings were consistent with other results used as a reference to build this research hypothesis. In practice, leaders and managers of private higher education who give great attention to managerial commitment, system perspective, openness and experimentation, knowledge transfer and integration tend to have lecturers who have altruism, conscientiousness, courtesy, sportsmanship, and civic virtue. This is consistent with the results of correlational analysis between indicators which confirm that all learning organization indicators have a significant relationship with all OCB indicators. These findings are consistent with the results of Jo and Joo (2011) and Arma et al. (2016) who show that learning organization affects OCB. Besides, leaders and managers of private higher education that have an adequate reward system, which is characterized by the provision of wages/salaries, benefits, additional income, feelings of ability, skills, personal growth, and responsibilities according to the needs and expectations of lecturers tend to motivate lecturers to show extra-role behavior through altruism, conscientiousness, courtesy, sportsmanship, and civic virtue. This is consistent with the results of correlational analysis between indicators which show that all reward system indicators 
have a significant relationship with all OCB indicators. The research results of Rahman and Chowdhuri (2018) and Suryani et al. (2019) also prove that the reward system influences OCB. In reality, leaders and managers of private higher education that can manage and develop affective, normative, and continuance commitments of lecturers also well have great potential to encourage the emergence of extra roles of lecturers' roles manifested in altruism, conscientiousness, courtesy, sportsmanship, and civic virtue. This is consistent with the results of correlational analysis between indicators that prove all organizational commitment indicators have a significant relationship with all OCB indicators. Studies conducted by Agung and Sapta (2018) and Shahjehan et al. (2019) also report that organizational commitment affects OCB. Moreover, efforts of leaders and managers of private higher education to build optimally managerial commitment, perspective systems, openness and experimentation, knowledge transfer and integration of lecturers can also have implications for increasing the affective, normative, and continuance commitment of lecturers. As shown by the results of correlational analysis between indicators, all indicators of reward systems and organizational commitment are significant. The results of research by Maulana et al. (2019) and Beauregard et al. (2019) also indicate that learning organization influences organizational commitment. Finally, seriousness and success of leaders and managers of private higher education in building reward systems in the form of wages/salaries, benefits, additional income, feelings of ability, skills, personal growth, and responsibilities also can stimulate an increase in affective, normative, and continuance commitment among lecturers. This is consistent with the results of correlational analysis between indicators of the reward system variable and organizational commitment, which are all significant. The investigation of Chelangat and Gachunga (2016) and Widodo and Damayanti (2020) found that reward systems influence organizational commitment. The results of this study confirm the results of a number of such studies and moreover find a new empirical model based on the data of private higher education lecturers in Indonesia, which can be adopted as a theoretical (conceptual) model of future research that can be utilized by researchers concern on contemporary OCB issues. For organizational and management practitioners, this new model can be used as one of the strategic options in building OCB lecturers or employees. The focus is on the creative, innovative, and massive utilization of learning organizations, reward systems, and organizational commitment through organizational engineering, for example by optimizing learning organizations, reward systems, and organizational commitment. Such efforts can, for example, be pursued through new policies that enable organizations to truly act as learning organizations, namely places where students (members of the organization) continually expand their skills to create and achieve, places to encourage new patterns of thinking, places collective aspirations are learned, where students (members of the organization) learn how to learn together, and where organizations expand their ability to innovate and solve problems (Senge, 1990). In addition, the new policy can also be oriented towards improving the reward system, both in content and methods, so that it can trigger the emergence of a new spirit that initiates the growth of organizational commitment and OCB that is stronger and solid among lecturers or employees.

\section{Conclusion and Recommendation}

This research has proven that learning organization, reward system, and organizational commitment had a significant direct effect on $\mathrm{OCB}$, learning organization and reward system had a significant direct effect on organizational commitment, and then learning organization and reward system had a significant indirect effect on OCB by mediating organizational commitment. Therefore, a fit research model was found about the effect of learning organization and reward system on OCB by mediating organizational commitment with the research setting of the lecturers of private higher education in Indonesia. This model can be used as a reference by researchers and practitioners in developing models of OCB that are following their respective conditions and also be further developed and expanded into research, studies, and projects to develop OCB which is more complex, comprehensive, and holistic by adding variables, other relevant indicators, and other analysis approach as structural equation modeling (SEM) with SmartPLS software.

\section{Acknowledgments}

We are very grateful to the lecturers in Indonesia who volunteered to spend their time and full dedication to responding to every statement item in the questionnaire completely and perfectly so that it could be used as research material in this article. May this willingness and dedication be a contribution to the development of science that can seeding to civilization.

\section{References}

Arma, A.R., Hamzah, D., Alam, S., \& Ismail, P. M. (2016). Learning organization in the implementation of new public services at Palu Local Government, Indonesia. Quest Journals Journal of Research in Business and Management, 3(12), 8-19.

Balay, R. (2012). Effect of learning organization perception to the organizational commitment: A comparison between private and public universities. Educational Sciences: Theory \& Practice, 12(4), 2474-2486.

Basim, H.N., Şeşen, H., Sözen, C., \& Hazir, K. (2009). The effect of employees' learning organization perceptions on organizational citizenship behaviors. Selcuk University Social Sciences Institute Journal, 22(12), 55-66.

Beauregard, N., Lemyre, L., \& Barrette, J. (2019). The healthy learning organizations model: Lessons learned from the Canadian federal public service. Public Personnel Management, 1-21.

Bernardin, J.H. (2007). Human resources management: An experiential approach. New York: McGraw-Hill/Irwin.

Bikmaradi, A., Fardmal, J., \& Torabi, Y. (2018). Correlation of learning organization and intensive care nurses' organizational commitment of educational and therapeutic centers of Hamadan University of Medical Sciences in Iran. RevistaPublicando, 5(15)(, 395-409.

Byars, L.L., \& Rue, L.W. (2008). Human resource management. Boston: Irwin McGraw-Hill.

Chelangat, Z., \& Gachunga, H. (2016). Effect of reward management practices on organizational commitment in state corporations in Kenya: a case study of Kefir. The Strategic Business \& Change Journal of Management, 3(3), 325-346. 
Choi, W.S., Heo, J.S., \& Kim, L.J. (2015). A study on the impact of material, social, symbolic reward on OCB: Moderate effect of the rank. Journal of Economics, Business, and Management, 3(3), 377-382.

Dirani, K.M. (2009). Measuring the learning organization culture, organizational commitment and job satisfaction in the Lebanese banking sector. Human Resource Development International, 12(2), 189-208.

Greenberg, J. (2010). Managing behavior in organizations. Boston: Pearson, Prentice Hall, Inc.

Günay, G. Y. (2018). Relationship between job satisfaction, organizational citizenship behavior and employee performance: Sample of Edirne financial office employees in Turkey. American International Journal of Contemporary Research, 8(1), 64-74.

Hair, J.F., Balck, W. C., Babin, B. J., \& Anderson, R.E. Multivariate data analysis. 7th edition. Boston: Pearson.

Hanafi, A., Soebyakto, B. B., \& Afriyanti, M. (2018). The effect of organizational citizenship behavior (OCB) and quality of work-life (QWL) on employee work performance with motivation as an intervening variable at Industrial affairs of South Sumatera Province. International Journal of Scientific Research and Management (IJSRM), 06(09), EM-2018-676-685.

Jerez-Gomez, P., Cespedes-Lorente, J., \& Valle-Cabrera, R. (2005). Organizational learning capability: A proposal for measurement. Journal of Business Research, 58, 715-725.

Jo, S.J., \& Joo, B.K.B. (2011). Knowledge sharing: The influences of learning organization culture, organizational commitment, and organizational citizenship behaviors. Journal of Leadership \& Organizational Studies, 18(3), 353-364.

Kusumaninggati, M.M., \& Sujanto, B. (2018). The influence of self-efficacy, job satisfaction and organizational commitment toward organizational citizenship behavior (OCB) of teachers of private vocational schools in South Jakarta. International Journal of Scientific Research and Management (IJSRM), 06(06), 404-414.

Maulana, B., Matin, \& Heru. (2019). The effect of the learning organization and organizational culture on the commitment of Banten Province LPMP personnel. International Journal of Education, Information, Technology, and Others (IJEIT), 2(1), 26-36.

McKenna, E. (2006). Business and psychology: Organizational behavior. New York: Psychology Press.

McShane, S. L., \& Von Glinow, M.A. (2015). Organizational behavior: Emerging knowledge, global reality. $7^{\text {th }}$ ed. McGraw-Hill.

Meyer, J.P, \& Allen, N.J. (1997). Commitment in the workplace: Theory, research, and application. Thousand Oaks, California: SAGE.

Nazir, S., Shafi, A., Qun, W., Nazir, N., \& Tran, Q. D. (2016). Influence of organizational rewards on organizational commitment and turnover intentions. Employee Relations: The International Journal, 38(4), 1-27.

Pedler, M., Burgoyne, J., \& Boydell, T. (1997). The learning company: A strategy for sustainable development, $2^{\text {nd }}$ ed. McGraw-Hill.

Peleaşă, S. (2018). Grit utility in explaining the job and contextual performance. Studia Doctoralia Psychology and Educational Science, 9(15), 54-64.

Rahman, H.A., \& Chowdhuri, A.S.M.B. (2018). Effect of employee compensation on organizational citizenship behavior (OCB): A study on private commercial banks in Bangladesh. International Journal of Economics, Commerce and Management, VI(5), 848-863.

Robbins, S.P., \& Judge, T.A. (2017). Organizational behavior. England: Pearson Education Limited.

Saqib, S., Abrar, M., Sabir, H.M., Bashir, M., \& Baig, S.A. (2015). Impact of tangible and intangible rewards on organizational commitment: Evidence from the textile sector of Pakistan. American Journal of Industrial and Business Management, 5, 138-147.

Saxena, S., \& Saxena, R. (2015). Impact of job involvement and organizational commitment on organizational citizenship behavior. International Journal Management Business Research, 5(1), 19-30.

Senge, P.M. (1990). The fifth discipline: The art and the practice of the learning organization. New York: Doubleday.

Shahjehan, A., Afsar, B., \& Shah, S.I. (2019). Is organizational commitment-job satisfaction relationship necessary for organizational commitment-citizenship behavior relationships? A meta-analytical necessary condition analysis. Economic Research Ekonomska Istraživanja, 32(1), 2657-2679.

Sinnappan, L.P., \& Amulraj, M. (2014). Impact of rewards and recognition and empowerment on organizational citizenship behaviors among technical engineers. Management Studies and Economic Systems (MSES), 1(2), 89-95.

Slocum, Jr., J.W., \& Hellriegel, D. (2007). Fundamentals of organizational behavior. New York: Thompson South-Western.

Suresh, S., \& Venkatammal, P. (2010). Antecedents of organizational citizenship behavior. Journal of the Indian Academy of Applied Psychology, 36(2), 276-286.

Suryani, N.N., Gama, I.G., \& Parwita, G.B.S. (2019). The effect of organizational compensation and commitment to organizational citizenship behavior in the cooperative and small, middle enterprises department of Bali province. International Journal of Contemporary Research and Review, 10(1), 21210-21218.

Suwibawa, A., Agung, A.A.P., \& Sapta, I.K.S. (2018). Effect of organizational culture and organizational commitment to employee performance through organizational citizenship behavior (OCB) as intervening variables (study on Bappeda Litbang Provinsi Bali). International Journal of Contemporary Research and Review, 09(08), 20997-21013.

Tschannen-Moran, M. (2004). Fostering organizational citizenship in schools: Transformational leadership and trust. Journal of Educational Administration, 6, 1-36.

Vecchio, R.P. (2008). Organizational behavior. United State: Thomson South-Western.

White, M.A., \& Bruton, G.D. (2007). The management of technology and innovation: A strategic approach. Mason.

Widodo. (2019). Metodologi penelitian popular dan praktis. Depok: Rajawali Pers.

Widodo, W., \& Damayanti, R. (2020). Vitality of job satisfaction in mediation: The effect of reward and personality on organizational commitment. Management Science Letters 10, 2131-2138.

Williamson, I.O., Burnett, M.F., \& Bartol, K.M. (2009). The interactive effect of collectivism and organizational rewards on affective organizational commitment. Cross-Cultural Management: An International Journal, 16(1), 28-43.

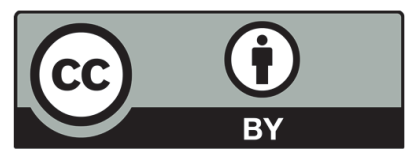

(C) 2020 by the authors; licensee Growing Science, Canada. This is an open access article distributed under the terms and conditions of the Creative Commons Attribution (CC-BY) license (http://creativecommons.org/licenses/by/4.0/). 